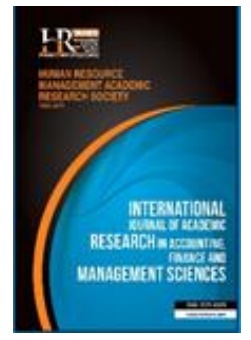

International Journal of Academic Research in Accounting, Finance and Management Sciences

Vol. 8, No.2, April 2018, pp. 259-271

E-ISSN: 2225-8329, P-ISSN: 2308-0337

(c) 2018 HRMARS

www.hrmars.com

To cite this article: Okoye, I., Ugochukwu, N.J., Chidoziem, A. M.-F. (2018). Forestalling Ingenious Approach to Financial Reporting in Post IFRS Regime in Dangote Cement Company Nigeria PLC, International Journal of Academic Research in Accounting, Finance and Management Sciences 8 (2): 259-271, http://dx.doi.org/10.6007/IJARAFMS/v8-i2/4380 (DOl: 10.6007/JJARAFMS/v8-i2/4380)

\title{
Forestalling Ingenious Approach to Financial Reporting in Post IFRS Regime in Dangote Cement Company Nigeria PLC
}

\section{Emmanuel Ikechukwu OKOYE ${ }^{1}$, John Ugochukwu NWOYE², Mary-Fidelis Chidoziem ABIAHU ${ }^{3}$}

${ }^{1,2,3}$ Department of Accountancy, Nnamdi Azikiwe University, PMB 5025, Awka, Anambra State ${ }^{3}$ E-mail: f.abiahu@unizik,edu.ng (Corresponding author)

Abstract

This research work focused on the role played by predictive models in proactively forestalling ingenious approaches otherwise known as creative accounting to IFRS based financial reporting practices of manufacturing companies. It examined the contributions made by the predictive models in predicting creative accounting practices in the selected manufacturing company in Nigeria, while making further effort at determining whether or not the predictive capabilities of the Beneish 8-Predictive variables and the Altman model differ significantly. The research work was quantitatively designed. Dangote Cement Plc, the only Nigerian manufacturing company that made the list of Forbes 2015 top 2000 companies in the world was purposively and judgmentally sampled. Thus, data obtained from secondary sources comprising Annual Reports and Audited Accounts of Dangote Cement Nigeria Plc (2000-2015), published journals, Articles, Inaugural lectures etc, were used for the successful completion of this work. Inputs from the Annual Reports and Accounts were analysed with the aid of Beneish 8-Predictive variables and Altman model using the Multiple Regression Analysis, and Wilxocon statistical techniques. The result of the analyses showed that the Beneish 8-Predictive variables made significant contributions in predicting possible Creative Accounting practices in Dangote Cement Nigeria Plc. It also found that there was no significant difference in the predictive capability of the Beneish 8-Predictive variables and the Altman Z-score model when jointly applied in predicting possible tendencies of Creative Accounting practices in publicly listed manufacturing companies in Nigeria. As a result, the study recommended that Professional Accountants and the Internal Auditors in Dangote Cement Company PIc need to tighten up their audit belt firmly and sceptically through the individual or joint discrete application of multiple Creative Accounting predictive and deterrence models/ratios to ensure that greater emphasis is also placed on the data integrity/quality of the financial reports and not just on their IFRS disclosure qualities.

Key words

Altman Model, Beneish 8-Predictive Variables, Creative Accounting Practices, Dangote Cement Company, Financial Data Integrity, IFRS

Received: 16 Jun 2018

Revised: 12 Jul 2018 Published by Human Resource Management Academic Research Society (www.hrmars.com)

Accepted: $28 \mathrm{Jul} 2018$ This article is published under the Creative Commons Attribution (CC BY 4.0) license. Anyone may reproduce, distribute, translate and create derivative works of this article (for both commercial and noncommercial purposes), subject to full attribution to the original publication and authors. The full terms of this license may be seen at: http://creativecommons.org/licences/by/4.0/legalcode

\section{Introduction}

With the prevailing economic crisis currently ravaging the domestic and global market, given the unfavourable upward fluctuations in the price of the US Dollar to Naira, Crude oil and Premium Motor Spirit (fuel), trials times appear to have set in once again for corporate organisations with their cash flows dwindling daily, thereby exposing them to possible financial setbacks and risks that could affect the confidence of Investors in such companies' going concern status. 
Executives of publicly listed companies or their Managers, being exposed to the pressure of retaining a good picture for the company, are often tempted to resort to ingenious and more often questionable procedures that usually lead to the refining of the company's accounts presentation.

Some scholars have viewed this methodological ingenious approach to accounting as creative or deceptive accounting. This is probably because, creativity as a word in accounting profession is widely used to describe accepted accounting techniques that permit corporate organisations to publish financial results that may not accurately portray the substance of their business activities (Karim et al., 2011) during a given period under review.

However, with the advent and development of the International Financial Reporting Standards in April 2001 by the International Accounting Standard Board (IASB) to foster comparability, accountability and transparency of Financial Statements across the globe, and its consequent adoption in Nigeria on $1^{\text {st }}$ January, 2012, expectations have risen on the imminent intervention of the Principle-based international accounting standards at effectively deterring incidence of material misstatement or creative accounting practices or manipulations in the published Financial Statements of Nigeria corporate organisations, and raising the confidence of local and international Investors on the quality and reliability of its content.

Although Nwoye et al. (2015) were of the view that the adoption and due compliance to IFRS guidelines does not in any way determine the integrity of the financial data disclosed by the companies' managements, Okoye (2016); Abu and Adetula (2015); and Lin, Hua, Lin, and Lee (2012), believed that high quality Accounting Standards could be effective at minimizing opportunities of earnings manipulation and fraudulent financial reporting.

Given the well documented history of business failures over the past five decades, it is quite surprising that substantial amount of research effort has been made empirically to the development of reliable means to help predict prevalence of creative accounting practices within the Nigerian business environ, especially in the manufacturing/industralised sectors. More worrisome is the fact that scholarly outputs available reveal that, unlike the banking and financial sectors that have enjoyed so much research patronage by the Accounting Academics in Nigeria, the manufacturing sector has suffered serious "empirical" scholarly drought in studies bordering creative accounting practices, fraud, bankruptcy etc, in Nigeria. Output of several Nigerian scholarly literatures on the subject such as Umoren, Oyerinde and Odejayi (2010); Osahon (2012); Akenbor and Ibanichuka (2012); Uwuigbe et al. (2012); Sanusi and Izedonmi (2014); Yadav (2014); Abu and Adetula (2015); Nwoye et al. (2017); ljeoma (2015); to mention but a few, also lend credence to the fact that this essential area of accounting research in Nigeria has continually lacked adequate empirical research approach and as a result, grossly and insufficiently researched within the practical context of using published financial data of publicly listed companies in Nigeria. Although Egbunike (2013) developed a modified version of the popular Altman Z-score model for predicting future occurrence of fraud that could lead to bankruptcy in a corporate organization, his unique empirical study dwelled (just like many others) solely within the banking industry; perhaps, as a research response to the then ongoing crisis in the financial sector.

Nigeria dreams of being among the $20^{\text {th }}$ best economy in the world by 2020 , yet lacks viable, growing and expanding industrial base that encourages investment attractive manufacturing indigenous owned publicly listed corporate organisations to spin up. Global evidence shows that all notable developed nations across the globe are known for one unique quality among others, and that is impressive industrialization. However, Dangote groups via Dangote Cement PIc has continued to lead the market capitalization table in Nigeria for quite some time now amidst competitively making appearance in world reputable international rankings such as Forbes top 2000 since 2012 till date.

Going by the company's laudable feat and consistent performance despite global hardship and economic recession as currently witnessed in Nigeria, how well are the Nigerian Accounting Academics and the Accounting professionals in practice doing to help encourage data integrity and transparency in Dangote Cement PIc's financial reporting practices, seeing that the company's slippery liquidity status may, after all, constitute a threat/challenge in her upholding sound financial reporting practices.

This effort is thus considered necessary towards ensuring that history that trailed the Nigerian banking sector which subsequently led to the untimely wind up/takeover of many respected Nigerian banks just few weeks/months after their receipt of international awards and the recollection of Cadbury Nigeria 
Plc 2002 - 2006 N13 billion fictitious revenue scandal that stretched over a period of 5 years, does not repeat itself.

Fewer tested and reliable creative accounting predictive models like the Beneish Model designed by an Indiana University Professor (Beneish, 1999) and also recommended by the Association of Certified Fraud Examiners (Cynthia, 2005) for external users of Financial Statements and the Altman model, are all equally insufficiently researched and applied in Nigeria, and in some cases where applied, are usually poorly interpreted in scientific papers for users, investors and creditors appreciation.

The aim of this research is to deploy these models/ratios for effective proactive deterrence of creative accounting practices in Financial Statements of Dangote Cement manufacturing company Nigeria Plc.

\subsection{Objectives}

1. To determine whether the Beneish 8-predictive variables make any significant contribution in predicting creative accounting practices in Dangote Cement Company Nigeria Plc.

2. To determine whether the predictive capabilities of the Beneish 8-predictive variables and the Altman model differ significantly.

\subsection{Hypotheses}

1. Beneish 8-predictive variables do not make any significant contribution in predicting creative accounting practices in Dangote Cement Company Nigeria Plc.

2. The predictive capabilities of the Beneish 8-predictive variables and Altman Z-scores do not differ significantly.

\section{Literature review}

\subsection{Conceptual Framework}

Financial Statement data that are free of error, whether in the form of mis-estimations, mistakes, biases, or manipulation, reduced accounting disclosures, are crucial for the smooth functioning of the Capital Markets and efficient resource allocation and contracting. Therefore, assessing the possible errors in financial statements is an important task for Investors, Analysts, Auditors, Regulators, and Researchers (Amiram et al., 2015).

Creative accounting since inception has been viewed as income smoothing, earnings management, earnings smoothing, financial engineering and cosmetic accounting (Karim et al., 2011). This evolved in Britannic economies due to the freedom ensured to the accounting professionals, and presently lies between legal form and the core of transactions or events (Diana and Madalina, 2007).

Balaciu et al. (2009) viewed the concept as the process through which accounting professionals use their knowledge of accounting regulations to manipulate the figures included in the annual accounts of a company. Copeland (1968) cited in Karim et al. (2011), stressed that creative accounting involves the repetitive selection of accounting measurement or reporting rules in a particular pattern, the effect of which is to report a stream of income with a smaller variation from trend than would otherwise have appeared.

Perhaps, that was why Malik and Tassadaq (2015) tagged it as "financial reporting gimmicks used to moderate company's financial reports so as to encourage investors to buy the company's stocks towards increasing the firm's market value. But Osisioma and Enahoro (2006) described it as manipulations prompted by accounting processes and choice of policies resulting from many judgments at the same time.

These above views, in summary, clearly show that when the figures of a company's financial accounting practices are transformed from what they actually are to what preparers desire by taking advantage of existing rules and/or ignoring some or all of them, creative accounting practices is said to be upheld in such an entity. No wonder Shah and Butt (2011) described it as a weapon used in critical times or situations of a firm.

This in essence, is the very reason why Investors and Professional Accountants must watch out for some sensitive choking smog that could pave way for entities to embrace creative accounting practices. 
Signs such as flexibility in regulations or Accounting standards especially in cases of use of professional judgment, lack or absence of competitive/reliable corporate regulations or accounting guidelines, existence of scope for management operation with assumed detailed targets for the future, timing of some transactions, use of artificial transactions, and the reclassification and presentation of financials, are often considered key sources of inspiration for creative accounting practices in corporate organizations.

\subsection{The development of Beneish 8-Predictive Variables}

Analysis ratios created and tested by an Indiana University Professor, Beneish Daniel Messod in 1999 show promises of exposing possible infractions towards enabling Auditors, Financial Analysts, Regulators, Forensic Accountants, Certified Fraud Examiners focus their attention into possible suspicions in a company's Financial Statements (Cynthia, 2005).

As a mathematical model, the Beneish 8-Predictive Variables contains 8 financial ratios whose parameters/variables are constructed from the company's Financial Statements, towards obtaining a Manipulation Score, upon appropriate application, that helps describe the degree to which the earnings of an organization has been altered or manipulated. Although very much similar in many ways to the Altman Z-Score (Stockopedia, 2011), it focuses solely on the detection and prediction of earnings manipulation or possible creative accounting practices rather than bankruptcy as is obtainable when the Altman Z-score model is applied.

The predictive ratios focusing on Financial Statement distortions capture unusual accumulations in receivables (DSRI, indicative of revenue inflation), unusual expense capitalization and declines in depreciation (AQI and DEPI, both indicative of expense deflation), and the extent to which reported accounting profits are supported by cash profits (Accruals) (Voisin, 2012).

The probability of creative accounting practices in an organisation goes even higher when unusual increases in receivables, deteriorating gross margins, decreasing asset quality, abnormal sales growth, and increasing accruals becomes the case in an entity. This should also be an area of great interest to Internal Auditors in Dangote Cement Company Nigeria Plc.

Given below are the 8 predictive variables and the consequent calculation approach deployable for their usage.

1. Days Sales Receivable Index (DSRI) $=\left(\right.$ Net Receivables $_{t} /$ Sales $\left._{t}\right) /\left(\right.$ Net Receivables $_{t-1} /$ Sales $\left._{t-1}\right)$

2. Gross Margin Index (GMI) $=\left[\left(\right.\right.$ Salest-1 $_{t}-$ Cost of Goods Sold $\left.t-1\right) /$ Sales $\left._{t-1}\right] /\left[\left(\right.\right.$ Sales $_{t}-$ Cost of Goods Sold $t$ ) / Sales $t]$

3. Asset Quality Index (AQI) $=\left[1-\left(\right.\right.$ Current Assets $_{t}+$ Plant, Property \&Equipment $t_{t}+$ Securities $\left._{t}\right) /$ Total Assets $\left._{t}\right] /\left[1\right.$ - ((Current Assets $t_{t-1}+$ Plant, Property \& Equipment $_{t-1}+$ Securities $\left._{t-1}\right) /$ Total $_{\text {Assets }}$ t-1 $\left.)\right]$

4. Sales Growth Index $(\mathrm{SGI})=$ Sales $_{t} /$ Sales $_{t-1}$ (for application purpose, Turnover figures should be used for Sales too)

5. Depreciation Index $(\mathrm{DEPI})=\left(\right.$ Depreciation $_{t-1} /\left(\right.$ Plant Property \& Equipment $t_{t-1}+$ Depreciation $\left.\left._{t-1}\right)\right) /$ (Depreciation $_{t} /$ (Plant, Property \& Equipment $t+$ Depreciation $\left.\left._{t}\right)\right)$

6. Selling, General \& Administrative Expense Index (SGAI) = (Selling, General \& Administrative Expense $_{t} /$ Sales $\left._{t}\right) /\left(\right.$ Selling, General \& Administrative Expense $_{t-1} /$ Sales $\left._{t-1}\right)$

7. Leverage Index (LVGI) $=\left[\left(\right.\right.$ Current Liabilities $_{t}+$ Total Long Term Debt $\left.t_{t}\right) /$ Total Assets $\left._{t}\right] /[($ Current Liabilitiest-1 $\left._{\text {+ Total Long Term Debt }}-1\right) /$ Total Assets $\left._{t-1}\right]$

8. Total Accruals to Total Assets (TATA) $=$ (Income from Continuing Operations $s_{t}-$ Cash Flows from Operationst) / Total Assetst

\subsection{Beneish 8-Predictive Variables Decision Rules}

DSRI > 1.465 = Possible indulgence into revenue inflation, long stretching of credit collection period to boost turnover so as to recognize revenue earlier enough in the current year's financial record even though cash for the said sales are recoverable the following year.( $\leq 1.031$ as no creative accounting region).

GMI > 1.193 = Signifies that Gross margin of company is deteriorating and company is more likely to take to creative accounting measures to maintain confidence in her shareholders and the investors $(\leq 1.014$ as no creative accounting region). 
AQI >1.254 = Tendencies of capitalizing and deferring costs that should have been expensed. $(\leq 1.039$ as no creative accounting region)

SGI >1.607= firms under possible pressure to alter figures in her favour so as to keep up appearance in the competitive market ( $\leq 1.134$ as no creative accounting region).

TATA $>0.031=$ Accruals possibly used to engage in creative accounting. $(\leq 0.018$ as no creative accounting region).

DEPI > 1 = Tendencies of Assets being depreciated at a slower rate of depreciation to boost earnings. Thus, company could be making changes in her accounting policies by embracing revenue friendly depreciation policies

SGAI $\leq-\mathbf{1 . 0}=$ Company pushed into possible creative accounting practices to defer costs and expenses and consequently improve her profitability picture.

LVGI > $\mathbf{1}=$ Reflecting pictures of Increase in leverage. An increase in the indicator subjects a firm to a greater risk of violating debt covenants and engages in creative accounting activities in other to avoid a breech.

\subsection{The role of Altman Model}

The Altman model also known as the Z-score formula was introduced by Edward I. Altman in 1968 in predicting bankruptcy for companies. The score outlines five financial ratios, with all data obtainable from the company's financial statement. A score below 1.8 means the company is probably headed for bankruptcy, while companies with scores above 3.0 are not likely to go bankrupt. In a nutshell, the lower the score, the higher chances of bankruptcy (Aris et al., 2015).

The formula may be used to predict the probability that a firm will become insolvent within two years. Z-scores are used to predict corporate defaults and an easy-to-calculate control measure for the financial distress status of companies in academic studies.

The Z-score uses multiple corporate income and balance sheet values to measure the financial health of a company.

The Altman Z-score is calculated as follows:

Z-Score $=1.2 \times 1+1.4 \times 2+3.3 \times 3+0.6 \times 4+0.999 \times 5$

Where:

X1 (Working Capital/Total Assets)

X2 (Retained Earnings/Total Assets)

X3 (EBIT/Total Assets)

X4 (Market Value of Equity/Total Liabilities)

X5 (Sales/Total Assets)

Table 1. Altman Decision Rule

\begin{tabular}{|l|c|}
\hline Financially sound if greater than & 2.99 \\
\hline Caution required if between & $2.77-2.99$ \\
\hline Likely to go bankrupt within 2 years if between & $1.8-2.7$ \\
\hline Likelihood of bankruptcy is high if below & 1.88 \\
\hline
\end{tabular}

Source: Altman (2000)

\subsection{IFRS as a response to Creative Accounting Practices}

The pressure to globalize, no doubt, has led to the necessity of understanding the need for comparison of financial information across different corporate organisations (Sanusi and Izedonmi, 2014), towards ensuring that the business financial records maintain a true and fair view status.

This, it is believed, is the key focal objective of the International Financial Reporting Standards (IFRS) in its effort to achieve and sustain transparency, accountability, and comparability among adopters and users of the standards.

These standards began to emerge in the seventies upon the founding of the International Accounting Standard Committee (IASC) in 1972 by accounting bodies from nine countries. The committee, due to 
restructuring that was a response to evolving challenges and changes in the global market and the consequent effect of such changes on the accounting profession worldwide, became the International Accounting Standard Board (IASB) in 2001 with a new set of principle based international accounting standards known as International Financial Reporting Standards (IFRSs) rolled out from April 2001.

In the light of the increasingly global trend of IFRS, some developing economies have been quick to adopt IFRS as theirs national version of GAAP.

The increasing demand for greater transparency, consistency and more information disclosure in the Financial Statements of Dangote Cement manufacturing company. Nigeria Plc by investment opportunities' seekers cannot be overemphasized, even though accounting information comparability remains very crucial for Nigerian multinational manufacturing companies such as Dangote Cement Company Plc who also operates in other countries across Africa.

\subsection{Theoretical framework}

Financial Statements are drawn to present fair information about the financial position, operating performance and cash flows of the company (Kanapickiene and Grundiene, 2015). The reason for that is that the owners of companies, Investors, Creditors, governmental institutions make decisions regarding the development of the company on the basis of the information provided in Financial Statements.

In accounting practice and audit performance, detection of creative accounting practices in Financial Statements, in most cases, is analysed from the perspective of Audit-Fraud risk factors identification and Fraud risk assessment. But in interdisciplinary scientific research of informatics, accounting and audit, the analysis of models that could help detect creative accounting practices and fraudulent issues in the Financial Statements of corporate organizations could sometimes be very complex towards the Audit process. As a result, theoretical research studies often investigate issues of creative accounting in Financial Statements and their possible predictions and detections by means of financial ratios. Students of Cornell University while using the M-score model also correctly predicted and identified Enron as an earnings manipulator, even when experienced financial analysts failed to do so (Brickel, 2011). The model also correctly identified 12 of the 20 biggest frauds from 1997-2002, including Enron, Global Crossing and Adelphia (Shortzilla, 2012).

Beneish (1999) utilized these 8-Predictive variables in assessing all companies in the Compustat database from 1982 to 1992, towards detecting which of the years' financial statements have been subjected to any form of manipulation by the companies' management. Okoye and Nwoye (2014) deployed these variables in their historical study of Cadbury Nigeria Plc for the years 1995 - 2013, with $2002-2006$ serving as the experimental year for the variables confirmation.

\subsection{Empirical review}

The list of cases of creative accounting practices of corporate bodies in Nigeria still serve as a reference point for researchers and potential investors, even as investigation appear to be ongoing regarding some of such cases of unethical practices still pending in court and/or being considered by the EFCC.

Osahon (2012) explored and tested the views of 140 professional Accountants and Stock Brokers from ten (10) selected professional firms in Benin City using the Chi Square statistical tool and found out that the practice of creative accounting, which is obtainable in the country among publicly listed corporate and privately owned organizations, significantly and positively impacts on firms' value in Nigeria, amidst affecting their share price.

Akenbor and Ibanichuka (2012) in their study focused on prevalent creative accounting practices obtainable in Nigerian Banks. A total of fifty )50) respondents comprising 25 Managers and 25 Accountants of twenty-five (25) recapitalized banks operating in the Federal Capital Territory, Abuja were explored. Although they made unique findings after testing their hypotheses using the Z-test statistical tool (creative accounting practices influences market shares of companies, even as accounting principles and rules should be streamlined to reduce diversities of professional judgment in financial reporting), they failed to approach the study empirically towards pin pointing possible financial areas of the banks' operations that 
may have been undermined through creative accounting practices towards boosting the market shares of Nigeria companies.

Uwuigbe, Fagbemi and Anusiem (2012) examined the financial statements of seventeen (17) banks in Nigeria for the years $2004-2009$ to determine whether income smoothening existed in the published financial statement of banks covered. Using the Ordinary Least Square (OLS) and the Pearson Correlation statistical tools, they found out that the banks' ownership structure as well as banks with a higher proportion of non-executive directors in their Audit committees tends to have positive deterrence influence on the Income smoothing practices in the banks studied.

Sanusi and Izedonmi (2014) equally carried out a study that maintained sole emphasis on the commercial banks. As much as the study was deemed to be an empirical study focusing on creative accounting practices obtainable in selected commercial banks in Nigeria, the authors ended up designing the study using the survey research methodology, while employing the Z-test statistical tool for analyzing the views of a sample comprising 84 Managers/Assistant Managers and Accountants/Assistant Accountants. Their findings showed that Creative accounting practices in Nigerian commercial banks helps boost the market value of shares; even as users of accounting information are adversely affected by its practice in Nigeria.

In a study carried out in India by Yadav (2014), the opinion of selected 60 respondents of professional Chartered Accountants, Company Secretaries, Accounting Academics, and Accounting Students accountants, which were analysed using Factor Analysis analytical tool, showed that a positive correlation between creative accounting and internal control mechanism exist, The study however failed to proffer realistic means or functional techniques with which such practices can be predicted in order to be discouraged in the organization.

Eyira and Okeoma (2014) studied ten middle and top management staff members of 14 publicly listed companies in Nigeria (sample size of 140) with the intent of ascertaining the impact of creative accounting on the effectiveness of selected Nigerian manufacturing companies. Although the study's focus was not to predict or detect any possible practices of creative accounting in the organizations covered in the research, it failed to give sensitive attention to such areas considering the fact that the study equally maximized quantitative data (financial statements) towards attaining the objectives of the study. Based on their findings, they however concluded that many manufacturing firms in Nigeria underperform but practice creative accounting to appear legitimate.

Onoja and Adaaja (2015) assessed how the pressure of the rising state of accounting scandals prompted by creative accounting practices in the organisation has impacted on the Auditors' responsibility for fraud detection. Maximising the survey research design, the response of a sample of 55 comprising Bankers, Accountants, Managers, and Investors were analyzed. Their findings however showed that there is a wide gap between the respondents' expectation and the present statutory requirements for Auditors. And this, they felt is the major cause of the pressure on the existing Auditors 'responsibilities in relation to creative accounting and fraud detection.

ljeoma (2015) carried out a survey of 100 practicing professional Accountants comprising Chartered Accountants, Certified Accountants, PhD and MSc academic degree holders in other to find out whether the use of forensic accounting techniques is effective in curbing creative accounting. Results of the KruskalWallis test performed showed that strong evidence exists on how effective the techniques used by forensic accountants are helping to curb the problem of creative accounting in corporate organisations. The study also discovered that the emergence of forensic accountants has restored confidence in the credibility of corporate firms and their report. The study however failed to showcase the practical means and procedures by which the forensic accounting techniques mentioned in the research work are applied towards curbing the incidence of creative accounting in business organisations.

\section{Methodology of research}

Being a case study, the Ex Post facto research design was adopted for the effective execution of this quantitative research. This is in view of the fact that Ex Post facto is a method that permits the possible assessment of records of events that have occurred with an existing available data that cannot be altered or manipulated by the investigator (Egbunike and Abiahu, 2017). The study considers it a befitting 
complement to the objective of quantitative research which on the other hand is geared towards developing and employing mathematical models, theories and hypotheses pertaining to natural phenomena. Hence, published unqualified Financial Statements whose financial data cannot be subjected to any form of alteration or further adjustment by the study seeing that they are already within the reach of the public and verifiable by any third party, were maximized for the effective application of the relevant financial ratios/models adopted for this study.

All Nigerian publicly listed manufacturing companies that made the list of Forbes 2015 ranking of top 2000 global companies in the world were sampled in this study. The decision was a direct response to the existing gap observed in existing studies of creative accounting practices in Nigeria, which in most cases, maintained emphasis mainly on the banking industry. But the fact that Dangote Cement Company Plc was the only Nigerian manufacturing company to attain this laudable and attractive global feat prompted the need for the sole consideration of the Cement giant for a closer empirical study in this research work.

Investigation period covered thirteen (13) years of Dangote Cement Nigeria PIc's financial reporting practices starting from year 2000 when Dangote Industries Limited took hold of 65\%stake of the defunct Benue Cement Company (BCC) via investment, through 2009 when Benue Cement Company and Dangote Cement Plc had a successful merger, to her recent last reporting date (2015). Challenges of accessibility to data compelled the study to exclude the years 2002 and 2003 reporting periods of Benue Cement Company from the relevant analyses carried out in this research work. The Beneish 8-Predictive Variables, Altman model, Multiple Regression, and the Related Samples Wilcoxon Signed Rank Test statistical tools were deployed for the different relevant analyses carried out in this research work with the aid of SPSS Ver 22.

\subsection{Justification for choice of analytical techniques}

Considering the focus and purpose of this study, the Beneish 8-Predictive Variables with existing professional recommendations by the Association of Certified Fraud Examiners (ACFE) and proven effective application in Nigeria by Okoye and Nwoye (2014) in the historical study of Cadbury Nigeria Plc (1995 2013) and the consequent confirmation of Cadbury's 2002 - 2006 scandal, is herein adopted and applied as a predictive tool (not a detective tool) towards deterring creative accounting practices among corporate organisations in Nigeria. The Altman Model became necessary to help corroborate the findings made by the Beneish 8-predictive variables especially at ascertaining the liquidity capacity of Dangote Cement Company across the years covered.

Using the Multiple Regression analysis was also considered very essential to enable the study appreciate the predictive ability or contribution made by each of the independent 8 predictive variables of the Beneish Model in predicting incidence of creative accounting in the company. The Related samples Wilxocon Signed Rank test was selected for use to enable us compare meaningfully, the individual different scores of the Beneish 8-predictive variables and the Altman model, towards ascertaining whether any significant difference exists between the two different creative accounting predictive models.

\section{Data analyses, results and discussions}

\subsection{Model Specification}

$Y=\alpha+B_{1} X_{1}+B_{2} X_{2}+B_{3} X_{3}+B_{4} X_{4}+B_{5} X_{5}+B_{6} X_{6}+B_{7} X_{7}+B_{8} X_{8}+\mu$

Where:

Y -Creative Accounting Predictor (DV)

$\alpha$-Constant

$\mu$-error term

$B_{1}-B_{8}$-Coefficients of the Independent Variables

$\mathrm{X}_{1}=\mathrm{DSRI} ; \mathrm{X}_{2}=\mathrm{GMI} ; \mathrm{X}_{3}=\mathrm{AQI} ; \mathrm{X}_{4}=\mathrm{SGI} ; \mathrm{X}_{5}=\mathrm{DEPI}$

$\mathrm{X}_{6}=\mathrm{SGAI} ; \mathrm{X}_{7}=\mathrm{LVGI} ; \mathrm{X}_{8}=$ TATA

Hypothesis One

$\mathrm{H}_{\mathrm{o}}$ :Beneish 8-predictive variables do not make any significant contribution in predicting creative accounting practices in Dangote Cement Company Nigeria Plc. 
Table 2. Model Summary

\begin{tabular}{|c|c|c|c|c|c|}
\hline Model & $\mathrm{R}$ & $\mathrm{R}$ Square & Adjusted R Square & Std. Error of the Estimate & Durbin-Watson \\
\hline 1 & 0.867 & 0.768 & .668 & 413.612 & 2.526 \\
\hline
\end{tabular}

a. Predictors: (Constant), TATA, DEPI, AQI, LVGI, DSRI, GMI, SGI

b. Dependent Variable: (DV)

Table 3. ANOVA

\begin{tabular}{|c|c|c|c|c|c|c|}
\hline & Model & Sum of Squares & $\mathrm{df}$ & Mean Square & $\mathrm{F}$ & Sig. \\
\hline 1 & Regression & 116894634.950 & 7 & 166956372.136 & 247.693 & $.000^{\mathrm{b}}$ \\
& Residual & 29103.263 & 5 & 55520.653 & & \\
& Total & 116891308.213 & 12 & & & \\
\hline
\end{tabular}

a. Dependent Variable: (DV)

b. Predictors: (Constant), TATA, DEPI, AQI, LVGI, DSRI, GMI, SGI, SGAI

Table 4. Coefficients ${ }^{a}$

\begin{tabular}{|c|c|c|c|c|c|c|}
\hline & \multirow[b]{2}{*}{ Model } & \multicolumn{2}{|c|}{ Unstandardized Coefficients } & \multirow{2}{*}{$\begin{array}{c}\text { Standardized Coefficients } \\
\text { Beta }\end{array}$} & \multirow[b]{2}{*}{$\mathrm{t}$} & \multirow[b]{2}{*}{ Sig. } \\
\hline & & $\mathrm{B}$ & Std. Error & & & \\
\hline \multirow[t]{9}{*}{1} & (Constant) & -617.057 & 5109.832 & & -.121 & .909 \\
\hline & DSRI & .781 & .044 & .078 & 17.800 & .000 \\
\hline & GMI & -469.901 & 5481.134 & .000 & -.086 & .935 \\
\hline & AQI & 48.662 & 7.747 & .005 & 6.281 & .002 \\
\hline & SGI & 88.394 & 1.466 & .995 & 60.288 & .000 \\
\hline & DEPI & -193.059 & 1138.919 & .000 & -.170 & .872 \\
\hline & LVGI & -480.468 & 6003.830 & .000 & -.080 & .939 \\
\hline & TATA & -4212.178 & 8417.773 & -.008 & -.500 & .638 \\
\hline & SGAI & 78.394 & 4.466 & .795 & 16.008 & .003 \\
\hline
\end{tabular}

Source: SPSS ver 22

\subsection{Result Discussion and Interpretation}

Table 2- the Model Summary, $\mathrm{R}^{2}$ which measured the overall goodness of fit of the regression equation, recorded a value of .768 (Adjusted $R^{2}$ value .668). This implies that the independent variables (Day's Sales Receivable Index, Gross Margin Index, Asset Quality Index, Sales Growth Index, Depreciation Index, Selling, General and Administrative Expenses Index, Leverage Index, Total Accruals to Total Asset Index) in the model explain $76.8 \%$ variation in the dependent variable (Creative Accounting Predictor).

The output of the Coefficient table as in table 4 equally throws more light on this as DSRI, AQI, SGI, and SGAI with P-values $.000, .002, .000$, and .003 , which are all less than 0.05 , made the most significant predictive contributions in predicting the possible exposure of Dangote Cement Company to creative accounting practices. Although GMI, DEPI, LVGI, and TATA predictive ability was not felt in this model, maybe for reasons of capturing a few positive predictions in the Beneish 8-predictive variables computation carried out, that does not in any way render them useless. Professional Accountants and users of these 8predictive variables must bear in mind that each of the Beneish 8-predictive variables only raise alarm where and when necessary, and not at all times.

This can also be verified from the result of the 8-predictive variables where DSRI as at 2001 with a score of 1.584 which is greater than the benchmark 1.465 (just few months after Dangote Industries Limited grasped $65 \%$ of Benue Cement Company investment worth) indicated the presence of pressure on the management of Benue Cement Company (BCC) to possibly soften its existing credit policies in order to boost turnover in the future and perhaps, recognise revenue earlier enough in her financial reports even when the cash for the said sales are yet to collected.

This sensitive belief of the study which is strictly based on the company's computed outcome of the DSRI variable and its relative benchmark, was further confirmed in the after years financial reporting practices of BCC where the company's DSRI for 2004, 2005, 2009 (merger year), 2010, 2012, 2013, and 
$2015(353813.7,4.093,12.829,2.498,2.010,1.531$, and 1.561) were all greater than the 1.465 benchmark, signifying high tendencies of revenue inflation to maintain face in the domestic and global market.

Although Dangote Industries Limited (DIL) acquired 65\% in BCC in 2000, her takeover in 2004 by DIL, and consequent successful merger between BCC and DIL to form Dangote Cement Plc in 2009, had all suddenly led to a commendable increase in the company's turnover, profit, and asset size except in 2004 (no sale that year), professional Accountants and Analysts will need to be clarified and assured on the extent to which such resources injection affected the company and the figures of her consequent financial reporting practices. This could be deduced from some sensitive disclosed items of BCC and Dangote Cement Financial Statements. Her Total Asset, Total Equity, and Turnover grew from N4.8 billion, N1.5 billion, and N791.4 million in 2000; N7.5 billion, N3.5 billion, and nil in 2004 (BCC takeover year by DIL); N398.6 billion, N211.5 billion, and N 202.5 billion (BCC/DIL merger financial report); to N1.1 trillion, N748..4 billion, and N389.2 billion. Thus, between 2000 and 2015, the company's Total Asset has grown by 99.6\%, while her Total Equity and Turnover maintained $99.8 \%$ each growth.

In 2004, the same year DIL took over BCC and thus made no sales and incurred no cost on sales, the company's SGI was 2.557 against 1.607 benchmark (considering the fact that the 2003 comparative figure was used), and this alone signalled tendencies of pressure for the company to engage in creative accounting practices so as to maintain presence and confidence in the market and amongst shareholders the following year (2005) and in the future (See Chart 4 in Appendix // for better clarification).

As much as professional Auditors, Analysts, and Forensic Accountants must approach decisions like this with caution so as not to undermine the possible integrity of an organisation especially where a takeover and change of ownership situation is involved, skeptical efforts must be made to substantiate the possible impact the resources injected through such takeover and change of ownership would have on the company's future sales/turnover. BCC's 2005, 2008, 2009, and 2010 SGI results (4005101, 3.006, 2.127, and 5.785 against 1.607 benchmark) indicated that the company may have been under pressure almost every year since 2004 to remain and retain its a household name status especially from 2010 (year after the merger) in the Nigerian capital market.

The size of her computed SGAI in 2004 (-293241.1) should also persuade an investigator to look deeper into the books and the internal controls of the company to see if the company has any hidden habit of deferring cost and expenses from the actual year they were incurred (years of possible loss/poor performance) to more profitable years ahead. Indicators obtained in 2005, 2006, 2007, 2009 (merger year), 2012, 2013, and $2015(-4.055,-1.057,-1.175,-1.096,-1.348,-1.196$, and -1.154 against $\leq-1.000)$ seem to lend support to these fears (See Chart 6 in Appendix II).

Meanwhile, computed output of the company's AQI showed that right from 2005 where her AQI was 103.37 against 1.254, BCC/Dangote Cement (except in 2012) appeared to have been capitalising some of its cost that should have ordinarily been expensed in the company's profit and loss account (See Chart 3 in Appendix II).

\section{Decision}

Based on the ANOVA table- table 3 , it was confirmed that the model is statistically significant seeing that the P-value given (.000) is less than 0.05 . We further used the F-table to check degree of freedom (df) 7 under 5 and this gave us a Table value of 0.397 .

Weighing this against the F-value given in the ANOVA table (247.693), and in line with the following decision rule- accept the null hypothesis if F-value of is less than the F-Table value, otherwise reject and accept the alternate hypothesis, we accept the Alternate hypothesis since the F-value (247.693) is greater than 0.397, and this means that the Beneish 8-predictive variables make significant contribution in predicting possible creative accounting practices in Dangote Cement Company Nigeria Plc.

Hypothesis Two

$\mathrm{H}_{\mathrm{o}}$ :The predictive capabilities of the Beneish 8-predictive variables and the Altman $\mathrm{Z}$ scores do not differ significantly. 


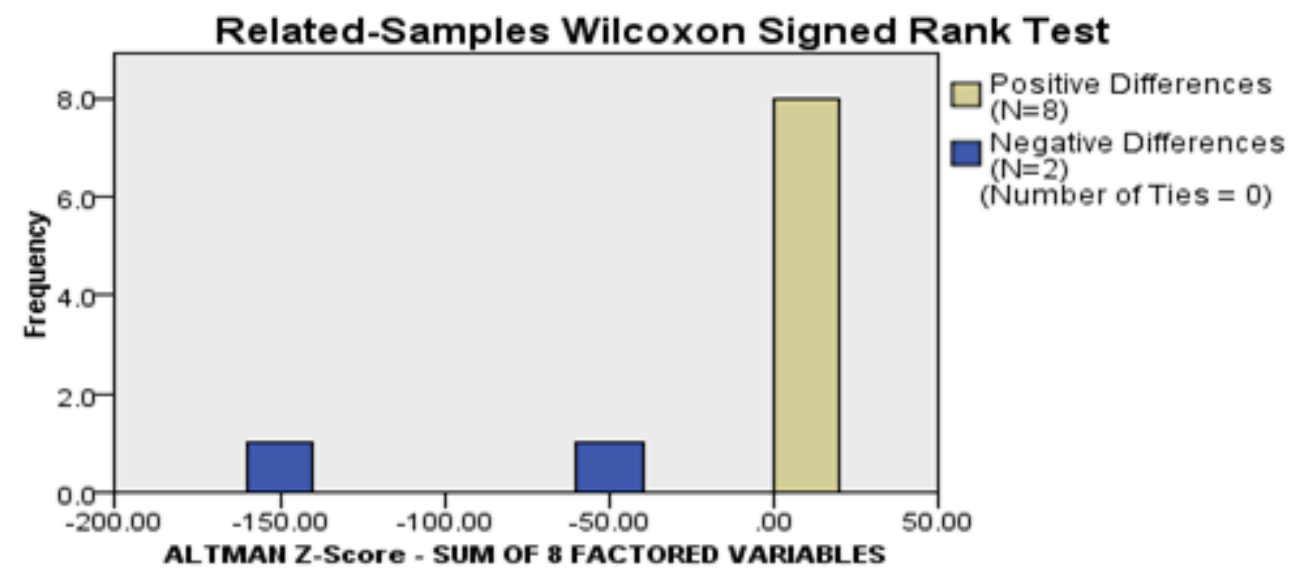

\begin{tabular}{|lr|}
\hline Total N & 10 \\
\hline Test Statistic & 36.000 \\
\hline Standard Error & 9.811 \\
\hline Standardized Test Statistic & .866 \\
\hline Asymptotic Sig. (2-sided test) & .386 \\
\hline
\end{tabular}

Figure 1. Wilxocon Signed Rank Test outcome

The result of the Wilxocon Signed test carried out showed that no significant difference exists in the predictive capabilities of the Beneish 8-predictive variables and the Altman Z-score model when jointly applied in the prediction of possible tendencies of creative accounting practices in Dangote Cement Company NigeriaPlc.

The above decision is based on the fact that the Asymptotic Sig or significance level or Probability value ( $P$-value) obtained in the analysis (.386) is greater than 0.05 .

Recall that when P-value $>0.05$, no significant difference can be said to exist between the two groups of items being ranked and evaluated. But when $P$-value $\leq 0.05$, a statistically significant difference can be said to exist.

This implies that the adequate employment and application of the Altman model on figures of Dangote Cement Company's published financial reports, which had earlier been subjected to the Beneish 8predictive variables scrutiny, helps complement the outcome of the Beneish 8-predictive variables computation towards reaching a constructive resounding conclusion on the Financial Statement data integrity and quality, and the consequent financial health of the cement giant un Nigeria. This could be corroborated with the result of the Altman Z-score which clearly showed that BCC/Dangote Cement had some serious liquidity challenges from 2006 - 2011, 2013 - 2015.

These lapses alone have the capacity of placing the company under pressure from time to time, even to considering creative accounting practices as a reliable alternative in making the books appear good and attractive annually. The company's Creative Accounting Predictors (CAP) for 2009, 2010, 2012, 2013, and $2015(161.18,47.489,-1.375,-1.556$, and -2.131) equally lend support to this findings. This is because, Creative Accounting Practices (CAP) could be perceived to become the fate of a company once the above indices obtained from the application of the 8-Predictive Variables is higher or greater than -2.22 (that is, a less negative or a positive number). This is a pointer that should also draw the attention of every skeptical professional Internal or External Auditor to the financials, internal controls, and accounting records of any enthusiastic growth oriented publicly listed manufacturing company. 


\section{Conclusions and recommendations}

The battle against Creative accounting practices which, oftentimes, lead to fraud in publicly listed corporate organisations on the long run, should no longer be fought reactively but proactively by professional Accountants in Practice, in Industries, and the Academics. Internal and External Auditors resolve to rightly, individually, and jointly deploy sensitive Creative accounting predictive models like the Beneish 8-predictive variables and the Altman Z-Score model, when carrying out various analytical Audit procedures, will be a far rewarding positive response towards installing the above expectations as stated.

Accountants, in Practice, Industries, and Academics, should therefore avail themselves of this opportunity to strengthen their resolve of making companies' annual financial stewardships free of any form of manipulation or creative accounting practices, through the practical deployment of the Beneish 8predictive variables as part of their substantive test kits during Audit. We also recommend the adoption and joint application of more than one creative accounting predicting ratios/models by professional Accountants and Internal Auditors at Dangote Cement Company Nigeria Plc for the sake of obtaining more reliable evidence or findings that could help boost effective prevention and deterrence of creative accounting practices in the future.

\section{References}

1. Abu, J.A \& Adetula, S.L. (2015). Creative accounting practice: Implication on investors, Journal of Educational Research in Natural and Social Sciences (JERNASS), 1(1), $109-119$.

2. Akenbor, C.O. \& Ibanichuka, E. A. L. (2012). Creative accounting practices in Nigerian Banks, International Multidisciplinary Journal, 6(3), $23-41$.

3. Altman, E. (2000). Predicting financial distress of companies: Revisiting the Z-score and ZETA models. Retrieved from http://scholar.google.com/scholar?hl=en\&btnG =Search\&q=intitle:PREDICTING+ FINANCIAL+DISTRESS+COMPANIES:+REVISITING+THE+Z-SCORE+AND+ZETA ${ }^{\circledR}+$ MODELS\#O

4. Amiram, D., Bozanic, Z. \& Rouen, E. (2015). Financial statement errors: Evidence from the distributional properties of financial statement numbers, Review of Accounting Studies, 20(4), 1540-1593.

5. Aris, N.A., Arif, S.M.M., Othman, R., \& Zain, M.M. (2015). Fraudulent financial statement detection using statistical techniques: The case of small medium automotive enterprise, The Journal of Applied Business Research, 31(4), $1469-1478$.

6. Balaciu, D. \& Madalina, P.C. (2007). Is creative accounting a form of manipulation? Economic Science Series, Annals of the University of Oradea, 935-940. Retrieved from: on-line at http://steconomice.uoradea.ro/anale/volume/2008/v3-finances-banks-accountancy/172.pdf

7. Balaciu, D., Bogdan, V. \& Vladu, A. (2009). A brief review of creative accounting literature and its consequences in practice, AnnalesUniversitatisApulensis Series Oeconomica, 11(1), 170-183

8. Beneish, M.D., (1999). Detection of earnings manipulation - Beneish Model.Retrieved from http://e8alpha.blogspot.com/2012/03/detection-of-earnings-manipulation.html

9. Benue Cement Company Nigeria PIc (2000 - 2009). Annual Accounts and Report.

10.Brickel, D. (2011, May). The Beneish M-Score: Identifying earnings manipulation and short candidates, Stockanalyst, Retrieved fromhttp://www.istockanalyst.com/finance/story/ 5179574/thebeneish-m-score-identifying-earnings-manipulation-and-short-candidates

11.Cynthia, H. (2005, March/April). Analysis ratios for detecting Financial Statement fraud, ACFE Fraud Magazine.

12.Dangote Cement Company Nigeria PIc (2010 - 2015). Annual Accounts and Report.

13. Egbunike, F.C. \& Abiahu, M.F.C. (2017). Audit firm report and financial performance of money deposit banks in Nigeria. The Nigerian Accountant. 50(1):25-39.

14.Egbunike, P.A. (2013). Modelling for fraud detection in financial statements: A Study of selected Banks (Doctoral Dissertation), Nnamdi Azikiwe University, Awka.

15.Eyira, C.M. \& Okeoma, E.C. (2014). The impact of creative accounting on organizational effectiveness: a study of manufacturing firms in Nigeria, British Journal of Economics, Management \& Trade, 4(12), 2107-2122. 
16.ljeoma, N.B. (2015). Empirical analysis on the use of forensic accounting techniques in curbing Creative accounting, International Journal of Economics, Commerce and Management, 3(1), 1- 15.

17.Karim, A.M., Fowzia, R., \& Rashid, M.M. (2011). Cosmetic accounting practices in developing countries: Bangladesh Perspectives, World Journal of Social Sciences, 1(3), 1-15.

18.Kanapickiene, R. \& Grundiene, Z. (2015). The Model of fraud detection in financial statements by means of financial ratios, Procedia - Social and Behavioral Sciences, 213, $321-327$.

19.Lin, C., Hua, C., Lin, W., \& Lee, W. (2012). IFRS Adoption and financial reporting quality: Taiwan Experience, $285-294$.

20.Malik, Q.A. \& Tassadaq, F. (2015). Creative Accounting and Financial Reporting: Model Development and Empirical Testing, International Journal of Economics and Financial, 5(2), 544-551.

21.Nwoye, U.J., Obiorah, J.N., \& Ekesiobi, C. (2015). Assessing the Risk of Fraud in Published IFRS and Nigerian GAAP Financial Reports: A Comparative Application of the Beneish Models, IUP Journal of Accounting Research and Audit Practices, India, 14(1), 21 - 42.

22.Nwoye, U.J., Abiahu, M.C., Ekesiobi, C. \& Obiora, J. (2017). Nigerian banks and global ranking: The IFRS compliance impact. The Nigerian Accountant: The Official Journal of the Institute of Chartered Accountants of Nigeria (ICAN). 50(2), 28-37.

23.Okoye, E.I., \& Nwoye, U.J. (2014). Skeptically Forestalling Fraudulent Financial Reporting In Publicly Listed Manufacturing Companies in Nigeria: The Role of the Beneish Model, Journal of Global Accounting, 3(1), $35-44$.

24.Okoye (2016). Anatomy of fraud and corruption in Nigeria: A search for the Pandora Box and panacea. An Inaugural lecture presented at the NnamdiAzikiwe University Awka, 18 August, Onitsha: Noben Press Limited.

25.Onoja, E.E. \& Adaaja O.E. (2015). The Effects of Creative Accounting and Its Burden on Auditors' Responsibilities in Nigeria, Journal of Good Governance and Sustainable Development in Africa (JGGSDA), 2(4), 96-108.

26.Osahon, O.H. (2012). Creative Accounting and Firm's Market Value in Nigeria, Arabian Journal of Business and Management Review, 2(3), 38 - 50.

27.Osisioma, B. C. \& Enahoro, J. A. (2006). Creative Accounting and Option of Total Quality Accounting in Nigeriall; Journal of Global Accounting; 2(1), 5-15.

28.Sanusi, B. \& Izedonmi, P.F. (2014). Nigerian Commercial Banks and Creative Accounting Practices, Journal of Mathematical Finance, 4, 75-83.

29.Shah, S.Z.A. \& Butt, S. (2011). Creative Accounting: A Tool to Help Companies in a Crisis or a Practice to Land Them into Crises, International Conference on Business and Economics Research IPEDR, 16, $96-102$.

30.Umoren, A.O., Oyerinde, D., \& Odejayi, D. (2010). Determinants of Creative Accounting, The Social and management scientists, $4(1), 90-98$.

31.Uwuigbe, O.R., Fagbemi, T.O. \& Anusiem U.F. (2012). The Effects of Audit Committee and Ownership Structure on Income Smoothening In Nigeria: A Study of Listed Banks, Research Journal of Finance and Accounting, 3(4), $26-33$.

32.Using Beneish's M Score to Detect Short Opportunities, (2012, March). Shortzilla,Retrived from http://www.shortzilla.com/blog/using-beneishs-m-score-to-detect-short-opportunities/

33.Voisin, F. (2012). What is the Beneish M-Score? Retrieved from http://www. frankvoisin.com/ 2012/05/30/what-is-the-beneish-m-score/

34.Wilkinson, B. (2009). Predicting the risk of corporate failure for Australian listed companies: A fresh approach using probability based tri dimensional modeling (Master's Thesis), University of Wollongong. Retrieved from http://ro.uow.edu.au/theses/3092

35.Yadav, B. (2014). Creative Accounting: An Empirical Study from Professional Prospective, International Research Journal Consortium, 3(1), 38-53. Retrieved from www.irjcjournals.org 